\title{
PENGARUH PARTISIPASI ANGGARAN TERHADAP KINERJA MANAJERIAL DENGAN MOTIVASI KERJA SEBAGAI VARIABEL PEMODERASI (Studi Kasus Pada Organisasi Perangkat Daerah (OPD) Di Kota Jayapura)
}

\author{
Iswahyudi ${ }^{1}$ \\ iswahyudi97@yahoo.com \\ Bill J. C. Pangayow, SE., M.Si, Ak ${ }^{2}$ \\ Anthonius H. C. Wijaya, SE., M.Sc., Ak, $\mathrm{CA}^{3}$ \\ Jurusan Akuntansi, Fakultas Ekonomi dan Bisnis Universitas Cenderawasih
}

\section{ABSTRACT}

The objectives in this study are: 1). To analyse the effect of budget participation on Managerial Performance on OPD in Jayapura City; and 2). To analyse the effect of budget participation on managerial performance of OPD in Jayapura City with work motivation as a moderating variable The population in this study were all civil servants in the Regional Devices Organizations (OPD) of the Jayapura City government consisting of 33 OPDs. The sample in this study amounted to 99 people. The statistical method used to test Hypotheses is simple regression and multilevel regression analysis with the interaction test approach Moderating Regression Analysis (MRA).

Based on the results of the study, the $t_{\text {count }}$ for the variable budget participation is 2.597 with a significance level of 0.012. With a significance level smaller than 0.05, H1 can be supported or in other words, government participation influences managerial performance. This proves that budget participation has a positive influence on managerial performance. The results of the analysis also show that, there is no influence between work motivation variables in moderating budgetary participation with managerial performance as indicated by the value of $t$ count of 0.030 with a significance of 0.976 which is greater than $\alpha=0.05$. Thus, the results of this study state that increasing work motivation does not cause an increase in managerial performance that participates in the budget.

Keyword $\quad$ : budget participation, managerial performance, work motivation.

\section{PENDAHULUAN}

Implementasi dari perubahan Undang-Undang Nomor 23 Tahun 2014 dalam penyelenggaraan pemerintah di daerah saat ini merupakan inti yang tertuang dalam Undang-Undang tersebut. Hal ini menekankan pada desentralisasi yaitu pelimpahan wewenang dari pusat kepada daerah untuk mengatur dan mengurus urusan pemerintah dalam sistem Negara Kesatuan Republik Indonesia. Hakekat pemerintah menyerahkan wewenang urusan ke daerah adalah untuk menumbuh kembangkan dan mendorong pemberdayaan masyarakat, menumbuhkan prakarsa dan kreativitas, meningkatkan dan mengembangkan peran serta masyarakat dan fungsi DPRD. Kepala daerah mempertanggung jawabkan keuangan Negara tidak lepas dari pengesahan anggaran pemerintah daerah dan DPRD. Diterbitkannya UU Nomor 9 Tahun 2015 tentang Pemerintahan Daerah dan UU Nomor 25 Tahun

\footnotetext{
${ }^{1}$ Alumni Jurusan Akuntansi FEB Uncen

${ }^{2}$ Dosen Jurusan Akuntansi FEB Uncen

3 Dosen Jurusan Akuntansi FEB Uncen
} 
1999 tentang Perimbangan Keuangan antara Pemerintah Pusat dan Daerah yang kemudian diganti dengan UU Nomor 23 Tahun 2014 adalah jawaban dari tuntutan tersebut.

Anggaran merupakan komponen penting dalam organisasi. Pentingnya fungsi anggaran sebagai perencanaan dan pengendali organisasi, menjadikan penganggaran sebagai hal yang penting bagi keberhasilan suatu organisasi. Anggaran adalah sebuah rencana tentang kegiatan di masa mendatang, yang mengidentifikasikan kegiatan untuk mencapai tujuan. Perencanaan dan pengendalian mempunyai hubungan yang sangat erat. Perencanaan adalah melihat ke masa depan, menentukan kegiatan apa yang harus dilakukan untuk mencapai suatu tujuan. Pengendalian adalah melihat ke masa lalu, melihat apa yang senyatanya terjadi dan membandingkannya dengan hasil yang direncanakan sebelumnya. Sebuah organisasi membutuhkan anggaran untuk menerjemahkan keseluruhan strategi ke dalam tujuan jangka pendek dan jangka panjang (Sinuraya, 2009). Dengan berlakunya Undang-Undang tersebut, membawa konsekuensi bagi daerah dalam bentuk pertanggung jawaban atas pengalokasian dana yang dimiliki dengan cara yang efisien dan efektif, khususnya dalam upaya peningkatan kesejahteraan dan pelayanan umum kepada masyarakat.

Penyelenggaraan urusan pemerintahan yang menjadi kewenangan daerah didanai dari dan atas beban Anggaran Pendapatan dan Belanja Daerah (APBD), yang merupakan dasar pengelolaan keuangan daerah dalam masa satu tahun anggaran. Dalam Undang-undang Nomor 17 Tahun 2003 tentang Keuangan Negara Pasal 19 (1) dan (2) menyebutkan bahwa, dalam rangka penyusunan RAPBD Satuan Kerja Perangkat Daerah selaku pengguna anggaran menyusun rencana kerja dan anggaran dengan pendekatan berdasarkan prestasi kerja yang akan dicapai. Membangun suatu sistem penganggaran yang dapat memadukan perencanaan kinerja dengan anggaran tahunan akan terlihat adanya keterkaitan antara dana yang tersedia dengan hasil yang diharapkan. Sistem pengangguran seperti ini disebut juga dengan anggaran berbasis kinerja.

Pengukuran kinerja digunakan untuk menilai keberhasilan atau kegagalan pelaksanaan kegiatan/program/kebijakan sesuai dengan sasaran dan tugas yang telah ditetapkan dalam rangka mewujudkan visi dan misi pemerintah daerah. Salah satu aspek yang diukur dalam penilaian kinerja pemerintah daerah adalah aspek keuangan berupa anggaran berbasis kinerja. Untuk melakukan suatu pengukuran kinerja perlu ditetapkan indikator-indikator terlebih dahulu antara lain indikator masukan (input) berupa dana, sumber daya manusia dan metode kerja. Agar input dapat diinformasikan dengan akurat dalam suatu anggaran, maka perlu dilakukan penilaian terhadap kewajarannya. Dalam menilai kewajaran (input) dengan keluaran (output) yang dihasilkan, diperlukan penilaian kewajaran atas beban kerja dan biaya yang digunakan untuk melaksanakan suatu kegiatan.

Penelitian terdahulu yang menghubungkan partisipasi penyusunan anggaran dengan kinerja manajerial secara tidak langsung, Ermawati (2017) melakukan pengujian partisipasi anggaran dan kinerja manajerial melalui motivasi kerja dimana variabel tersebut berpengaruh secara signifikan. Chong dan Chong (2002) dan Pramesthiningtyas (2011) melakukan pengujian partisipasi anggaran mempunyai pengaruh tidak langsung terhadap kinerja manajerial, partisipasi anggaran berpengaruh terhadap kinerja manajerial melalui motivasi kerja sebagai variabel moderating.

Hasil penelitian yang bertentangan tersebut mendorong para peneliti agar memeriksa variabelvariabel yang terlibat, yang dapat menghubungkan partisipasi anggaran terhadap kinerja manajerial. Menurut Siagian (2003) bahwa kinerja manajerial dipengaruhi oleh gaji, lingkungan kerja, budaya organisasi, kepemimpinan dan motivasi kerja (motivation), disiplin kerja, kepuasan kerja, motivasi. Dalam penelitian ini peneliti meneliti tentang motivasi kerja. Jika motivasi baik maka kinerja yang dihasilkan juga akan baik karena merupakan faktor yang sangat menentukan kinerja.

Ketidakkonsistenan hasil-hasil penelitian terdahulu, membuat adanya keyakinan bahwa hubungan antar variabel-variabel tersebut dapat dipengaruhi oleh variabel lain. Adapun variabel lain 
dalam penelitian ini yaitu variabel Motivasi kerja sebagai variabel moderating. Menurut Govindarajan (1986), untuk mensiasati ketidakkonsistenan dari hasil penelitian tersebut, maka diperlukan adanya pendekatan kontigensi. Dalam studi ini, pendekatan kontigensi digunakan untuk mengevaluasi tingkat keefektifan hubungan partisipasi anggaran dan komitmen aparatur dengan kinerja manajerial melalui motivasi kerja.

Dengan demikian rumusan masalah dalam penelitian ini adalah: 1) Apakah partisipasi anggaran berpengaruh terhadap kinerja manajerial pada OPD di Kota Jayapura ?, dan 2). Apakah partisipasi anggaran berpengaruh terhadap kinerja manajerial OPD di Kota Jayapura degnan motivasi kerja sebagai variabel moderating?. Dengan tujuan penelitian yaitu: 1). Untuk menganalisis pengaruh partisipasi anggaran terhadap kinerja manajerial pada OPD di Kota Jayapura. dan 2). Untuk menganalisis pengaruh partisipasi anggaran terhadap kinerja manajerial OPD di Kota Jayapura dengan motivasi kerja sebagai variabel moderating.

\section{TINJAUAN PUSTAKA}

\subsection{Teori Kontingensi (Contingency Approach)}

Menurut (Putti, Koontz, Weihrich, 1998: 60-61) Teori kontingensi juga dikenal orang sebagai teori situasional. Mengingat kompleksitas lingkungan yang dihadapi setiap organisasi, maka perlu dipahami, penjelasan teori kontigensi yang menyatakan bahwa tidak ada satu pun teori yang efektif dalam hal menangani segala macam situasi, hanya bisa dijelaskan oleh pendekatan tertentu saja, dengan perkataan lain: “... tidak ada satu cara tunggal terbaik untuk melaksanakan kegiatan manajemen" (there is no best way to manage).

Hoque dalam Abdullah dan Laksmana (2009) Teori kontigensi menyatakan bahwa rancangan dan kegunaan sistem pengendalian suatu organisasi merupakan sesuatu yang dependen atau bergantung pada konteks setting/lingkup organisasi. Match/sejajar yang lebih baik antara kesesuaian pengendalian suatu organisasi dengan variabel kontijensi seperti Partisipasi Anggaran, Komitmen Aparatur (anggota organisasi), motivasi kerja, diprediksikan menghasilkan kinerja manajerial yang meningkat.

Pendekatan kontijensi digunakan untuk mengatasi ketidak konsistenan hasil-hasil penelitian yang telah dilakukan sebelumnya. Penelitian ini memberikan suatu gagasan bahwa sifat hubungan yang ada antara partisipasi anggaran dan kinerja manajerial mungkin berbeda pada setiap kondisi (Pramesthiningtyas, 2011). Salah satu variabel kondisional tersebut adalah variabel intervening. Dalam penelitian ini, variabel intervening yang digunakan yaitu motivasi kerja yang dianggap mampu menjadi mediasi dalam hubungan antara partisipasi anggaran dengan kinerja manajerial.

\subsection{Teori Motivasi}

Motivasi berasal dari kata Latin movere yang berarti dorongan atau gerakan. Motivasi (motivation) dalam manajemen hanya ditujukan pada sumber daya manusia umumnya dan bawahan khususnya. Motivasi mempersoalkan bagaimana caranya mengarahkan daya dan potensi bawahan, agar mau bekerja sama secara produktif berhasil mencapai dan mewujudkan tujuan yang telah ditentukan. Pentingnya motivasi karena motivasi adalah hal yang menyebabkan, menyalurkan dan mendukung perilaku manusia, supaya mau bekerja giat dan antusias mencapai hasil yang optimal (Hasibuan, 2009 : 141). Terdapat berbagai macam teori mengenai motivasi. Kebutuhan merupakan keinginan psikologis atau keinginan psikologis yang tidak terpenuhi dalam diri seorang individu. 


\subsection{Anggaran}

Anggaran merupakan suatu rencana kerja yang dinyatakan secara kuantitatif, yang diukur dalam satuan moneter standar dan satuan ukuran yang lain, yang mencakup jangka waktu satu tahun (Mulyadi, 2001:488). Anggaran disusun manajemen dalam jangka waktu satu tahun untuk membawa perusahaan ke kondisi tertentu yang diperhitungkan. Dengan anggaran, manajemen mengarahkan jalannya perusahaan.

Anggaran menurut Supriyono (1999 : 340) adalah "Suatu rencana terinci yang dinyatakan secara formal dalam ukuran kuantitatif untuk menunjukkan bagaimana sumber-sumber akan diperoleh dan digunakan selama jangka waktu tertentu, umumnya satu tahun".

Anggaran menentukan besarnya target penjualan, produksi, laba, netto, posisi kas, dan semua sasaran lain yang ditetapkan manajemen. Menurut Hansen dan Mowen (2004), anggaran adalah "rencana keuangan untuk masa depan yang mengidentifikasikan tujuan dan tindakan yang diperlukan untuk mencapainya.

Agar proses penyusunan anggaran dapat menghasilkan anggaran yang dapat berfungsi sebagai alat pengendalian, proses penyusunan anggaran harus mampu menanamkan "sense of commitment" dalam diri penyusunnya. Proses penyusunan anggaran yang tidak berhasil menanamkan "sense of commitment" dalam diri penyusunnya berakibat anggaran yang disusun tidak lebih hanya sebagai alat perencanaan berkala; yang jika terjadi penyimpangan antara realisasi dari anggarannya, tidak satu pun manajer yang merasa bertanggung jawab. Anggaran merupakan suatu rencana kerja jangka pendek yang disusun berdasarkan rencana kerja jangka panjang yang ditetapkan dalam proses penyusunan program (programming)".

\subsection{Partisipasi Anggaran}

Partisipasi anggaran merupakan suatu proses yang melibatkan individu-individu secara langsung di dalamnya dan mempunyai pengaruh terhadap penyusunan tujuan anggaran yang prestasinya akan dinilai dan kemungkinan akan dihargai atas dasar pencapaian tujuan anggaran mereka (Nurcahyani, 2010). Partisipasi anggaran adalah tahap partisipasi pengurus dalam menyusun anggaran dan pengaruh anggaran tersebut terhadap pusat pertanggung jawaban. Brownell dalam Nurcahyani, 2010 mendefenisikan bahwa anggaran adalah suatu proses partisipasi individu akan dinilai dan mungkin diberi penghargaan atas prestasi mereka pada tujuan yang dianggarkan, dan mereka terlibat dalam proses tersebut dan mempunyai pengaruh pada penentuan tujuan tersebut.

Proses penyusunan anggaran bisa dari atas ke bawah bisa juga sebaliknya dan ada pula yang menggunakan gabungan keduanya. Berikut penjelasan mengenai pendekatan dalam proses penyusunan anggaran:

1. Top-down Approach (Pendekatan dari atas ke bawah)

Dalam pendekatan ini proses penyusunan anggaran dimulai dari manajer puncak, anggaran disusun dan ditetapkan sendiri oleh pimpinan dan anggaran harus dilaksanakan bawahan tanpa keterlibatan bawahan dalam penyusunannya.

2. Bottom-Up Approach (Pendekatan dari bawah ke atas)

Dalam pendekatan ini, anggaran disusun berdasarkan hasil keputusan karyawan. Anggaran disusun mulai dari bawahan sampai ke atasan. Bawahan diserahkan sepenuhnya untuk menyusun anggaran yang akan dicapainya di masa yang akan datang. 


\section{Participative Budget (Anggaran partisipasi)}

Pendekatan penganggaran yang melibatkan manajer level menengah dalam pembuatan estimasi anggaran disebut participative budget. Anggaran partisipasi adalah anggaran yang dibuat dengan kerjasama dan partisipasi penuh dari manajer pada semua tingkatan.

\subsection{Motivasi Kerja}

Motivasi adalah keadaan dalam pribadi seseorang yang mendorong keinginan individu melakukan kegiatan-kegiatan tertentu untuk mencapai tujuan (Pramesthiningtyas, 2011). Motivasi atau dorongan untuk bekerja ini sangat menentukan bagi tercapainya suatu tujuan, untuk itu seorang pegawai/manajer harus dapat menumbuhkan motivasi kerja setinggi-tingginya bagi diri nya untuk tercapainya tujuan perusahaan. Menurut Pramesthiningtyas (2011), motivasi merupakan kekuatan relatif dari dorongan yang timbul dalam diri pegawai untuk berusaha seoptimal mungkin dalam mencapai tujuan yang dipengaruhi oleh kemampuan usaha untuk memuaskan kebutuhan.

Motivasi erat hubungannya dengan timbulnya suatu kecenderungan untuk berbuat sesuatu guna mencapai tujuan. Motivasi timbul karena adanya suatu kebutuhan dan karenanya kebutuhan tersebut terarah pada pencapaian tujuan tertentu. Apabila tujuan telah tercapai, maka akan tercapai kepuasan dan cenderung untuk diulang kembali, sehingga akan lebih kuat (Pramesthiningtyas, 2011).

\subsection{Kinerja Manajerial}

Kinerja manajerial dalam penelitian ini adalah seberapa efektif dan efisien individu telah bekerja untuk mencapai tujuan organisasi, kegiatan manajerial yang dimaksud dalam penelitian ini adalah perencanaan, investigasi, pengkoordinasian, evaluasi, pengawasan, pengaturan staff, negosiasi dan perwakilan atau representasi (Kusuma (2013). Kinerja manajerial merupakan salah satu faktor yang dapat dipakai untuk meningkatkan efektivitas organisasi (T. Hani Handoko, 1996:34). Kinerja akan dikatakan efektif apabila pihak-pihak bawahan mendapat kesempatan terlibat atau berpartisipasi dalam proses penyusunan anggaran. Ketika suatu anggaran dirancang secara partisipatif maka karyawan akan memiliki rasa tanggungjawab pribadi untuk mencapai standar yang ditetapkan karena mereka ikut serta terlibat dalam proses penyusunannya yang akan berpengaruh pada tingkat kinerja.

Untuk mencegah dampak fungsional atau disfungsionalnya, sikap dan perilaku anggota organisasi dalam penyusunan anggaran, perlu melibatkan manajemen pada level yang lebih rendah sehingga anggaran partisipatif dapat dinilai sebagai pendekatan manajerial yang dapat meningkatkan kinerja setiap anggota organisasi (Kusuma, 2013).

\subsection{Penelitian Terdahulu dan Pengembangan Hipotesis}

Model teori dalam penelitian ini adalah menyajikan pengaruh partisipasi anggaran, terhadap kinerja manajerial sebagai variabel dependen, melalui motivasi kerja sebagai variabel moderating.

\subsubsection{Partisipasi Anggaran Terhadap Kinerja Manajerial}

Penelitian mengenai partisipasi anggaran dan pengaruhnya terhadap kinerja manajerial merupakan suatu bidang penelitian yang banyak mengalami perdebatan dalam literatur akuntansi perilaku selama empat dasawarsa terakhir (Riyadi, 1998). Beberapa peneliti yang tertarik untuk meneliti pengaruh partisipasi anggaran terhadap kinerja manajerial, diantaranya Sukmantari dan Wirasedana (2015), Suryanawa (2008), Dharma (2004), Sinuraya (2009), Ridzal (2016), Nur indriantoro (1993) dan Brownell (1981) yang mengemukakan bahwa terdapat hubungan positif dan signifikan antara partisipasi anggaran dan kinerja manajerial. Sedangkan Kenis (1979), Hariyono 
(2010), Chong dan chong (2002) dan Pramesthiningtyas (2011) menemukan bahwa partisipasi anggaran tidak berpengaruh terhadap kinerja menejerial.

Penelitian tentang pengaruh partisipasi anggaran terhadap kinerja juga dilakukan oleh Kren (1992), yang menyatakan bahwa partisipasi akan mempengaruhi kinerja dengan tiga cara yaitu (1) melalui peningkatan komitmen untuk mencapai tujuan anggaran, (2) melalui perancangan tujuan anggaran yang lebih tinggi, (3) melalui keuntungan kognitif yang berasal dari pembagian informasi selama partisipasi.

\section{H1 : Partisipasi anggaran berpengaruh positif signifikan terhadap Kinerja Manajerial.}

\subsubsection{Partisipasi Anggaran dan Motivasi Kerja Terhadap Kinerja Manajerial}

Partisipasi anggaran merupakan keterlibatan antara manajer atas dengan bawah untuk menentukan proses penggunaan sumber daya pada aktivitas dan operasi instansi (Eker, 2007). Brownell dan Mc. Innes (1986) memasukkan variabel motivasi yang bersandar pada teori ekspektasi sebagai variabel intervening untuk menguji hubungan partisipasi anggaran dengan kinerja karyawan. Hasil penelitian tersebut menemukan bukti bahwa motivasi dan partisipasi anggaran memiliki hubungan dengan kinerja karyawan secara langsung. Meskipun demikian, penelitian tersebut ternyata gagal menemukan bukti bahwa partisipasi akan meningkatkan kinerja manajerial melalui peningkatan motivasi. Sejalan dengan penelitian yang dilakukan oleh Pramesthiningtyas (2011) yang menggunakan variabel intervening komitmen organisasi dan motivasi kerja untuk menjelaskan pengaruh partisipasi anggaran terhadap kinerja manajerial dan dari penelitian tersebut ditemukan bukti bahwa partisipasi anggaran berpengaruh terhadap kinerja manajerial melalui komitmen organisasi.

Namun, melalui motivasi kerja sebagai variabel intervening tidak berpengaruh. Penelitian Cherrington dan Cherrington (1973) menyimpulkan bahwa faktor motivasi berupa reward sebagai variabel intervening berpengaruh kuat terhadap hubungan antara partisipasi anggaran dengan kinerja manajerial. Sesuai dengan teori motivasi, seseorang berprilaku untuk dapat memenuhi kebutuhan pada dirinya. Dengan adanya motivasi ini, para manajer dan supervisor akan bekerja lebih giat agar dapat mencapai tujuan instansi. Hal ini tentunya akan meningkatkan kinerja manajerial.

H2 : Motivasi kerja memperkuat berpengaruh partisipasi anggaran terhadap kinerja manajerial.

\subsection{Model Penelitian}

Dari hasil pembahasan diatas makan dikembangkanlah suatu model pemikiran dan hipotesis atas penelitian ini:

\section{Gambar 1

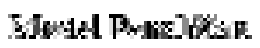

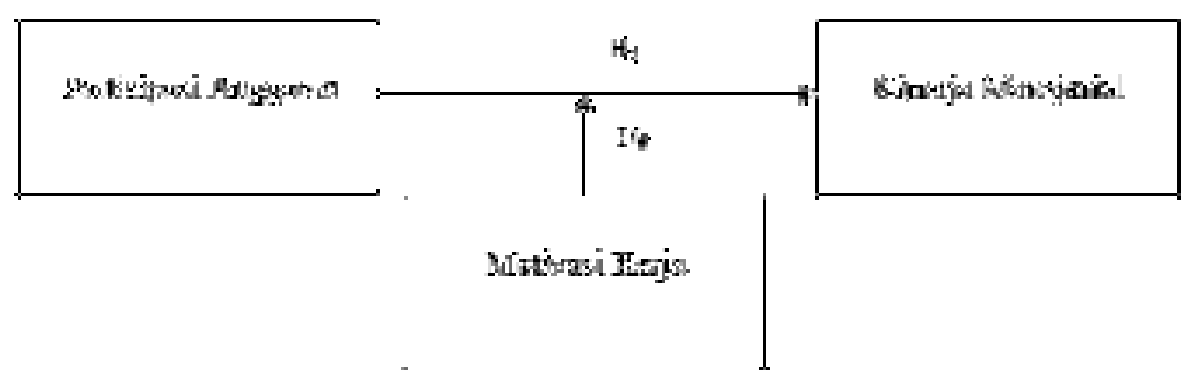




\section{METODE PENELITIAN}

\subsection{Objek Penelitian}

Objek dari penelitian ini adalah seluruh Organisasi Perangkat Daerah (OPD) pada pemerintah Kota Jayapura dengan dibatasi pada manajerial OPD dalam penyusunan anggaran OPD, yaitu kepala satuan kerja selaku pengguna anggaran dan pejabat penatausahaan keuangan.

\subsection{Desain Penelitian}

Desain penelitian yang digunakan dalam penelitian ini adalah merupakan penelitian kausal (causal) atau hubungan sebab akibat. Umar (2008) mengungkapkan desain kausal berguna untuk menganalisis bagaimana suatu variabel mempengaruhi variabel yang lain, dan juga berguna pada penelitian yang bersifat eksperimen di mana variabel independennya diperlakukan secara terkendali oleh peneliti untuk melihat dampaknya pada variabel dependennya secara langsung. Rancangan penelitian ini dimaksudkan untuk memberikan bukti empiris dan menganalisis partisipasi anggaran sebagai variabel independen terhadap kinerja manajerial pada OPD di Kota Jayapura sebagai variabel dependen dan motivasi kerja sebagai variabel moderating.

\subsection{Jenis dan Sumber Data}

Data dalam penelitian ini adalah data kuantitatif. Sumber data dalam penelitian ini adalah data primer yaitu data dari sumber asli dan dikumpulkan secara khusus untuk memjawab pertanyaan penelitian. Data tersebut di peroleh dari hasil pengisian kuesioner dan data primer ini di peroleh dari pegawai yang terlibat langsung dalam partisipasi anggaran pada OPD di Kota Jayapura.

Data primer adalah data yang diperoleh langsung dari sumber atau tempat dimana penelitian dilakukan secara langsung (Indriantoro dan Bambang Supeno, 1999: 65). Data primer dalam penelitian ini di peroleh melalui kuesioner yang dibagikan kepada responden sehingga metode yang digunakan adalah metode survey. Jenis Penelitian dapat mengacu pada deskriptif, yaitu penelitian yang bersifat untuk mengetahui dan menjelaskan bagaimana kualitas kinerja manajerial.

Kaitannya dalam penelitian ini adalah berusaha untuk mengetahui pengetahuan akuntansi yang di miliki oleh pemerintah daerah dalam melaksanakan pekerjaannya di instansi tersebut. Jenis data yang digunakan adalah data subyek yaitu data penelitian yang dilaporkan sendiri oleh responden secara individual atau secara kelompok dari sumbernya. Data subyek selanjutnya diklasifikasikan berdasarkan bentuk tanggapan (respon) yang diberikan, yaitu lisan (verbal), tertulis (kuesioner) yang diajukan oleh peneliti. Sumber data yaitu dari data primer merupakan data yang diperoleh secara langsung dari jawaban kuesioner responden yaitu kepala satuan kerja selaku pengguna anggaran dan pejabat penatausahaan keuangan.

\subsection{Populasi dan Sampel}

Populasi dalam penelitian ini adalah seluruh pegawai negeri yang ada dalam Organisasi Perangkat Daerah (OPD) Kota Jayapura terdapat 33 OPD. Alasan dipilihnya populasi dan lokasi penelitian tersebut adalah ingin mengetahui sejauh mana tingkat partisipasi anggaran di OPD Kota Jayapura. Pengambilan sampel dalam penelitian ini ditentukan dengan menggunakan metode purposive sampling yang bertujuan untuk mendapatkan informasi dari individu maupun kelompok dengan sasaran yang tepat. Adapun responden atau sampel penelitian adalah OPD di Kota Jayapura. Metode penelitian yang di pakai survei adalah metode. Data diperoleh dengan menggunakan kuesioner yang disebar kepada OPD di Kota Jayapura yang merupakan responden atau sampel dalam penelitian ini. Sampel pada penelitian ini dibatasi pada elemen-elemen yang dapat memberikan 
informasi yang berkaitan dengan partisipasi anggaran, motivasi kerja serta kinerja manajerial pada OPD di Kota Jayapura, dan ditujukan kepada bagian penyusunan anggaran yang berada di setiap OPD Kota Jayapura sebanyak 3 orang, sehingga sampel yang digunakan dalam penelitian ini berjumlah 99 orang dari 33 OPD yang ada di Kota Jayapura.

\subsection{Metode Pengumpulan Data}

Data penelitian dikumpulkan dengan metode pengumpulan langsung dari responden itu sendiri karena responden dan tempat penelitian mudah untuk di jangkau oleh peneliti. Untuk mendapat tingkat respon yang tinggi, maka dilakukan hal - hal sebagai berikut : (1), Kuisioner dirancang dengan format yang menarik, pertanyaan yang diajukan singkat dan jelas dan waktu yang digunaka untuk mengisi kuisioner oleh responden adalah 10 menit; (2), Jaminan kerahasiaan data yang diperoleh; (3), Melampirkan surat izin penelitian; (4), Melakukan konfirmasi langsung dari responden. Tahap-tahap ini dilakukan untuk meningkatkan response rate mengingat untuk penelitian di Indonesia dengan mengambil data langsung melalui kuisioner. Sedangkan jumlah sampel yang harus dipenuhi adalah sebanyak 90 responden.

\subsection{Definisi Operasional dan Pengukuran Variabel}

Berdasarkan kerangka pemikiran dan rumusan variabel penelitian tersebut, maka dapat diuraikan definisi operasional yang digunakan dalam penelitian ini adalah sebagai berikut :

\section{Partisipasi Anggaran}

Partisipasi anggaran adalah suatu proses partisipasi individu akan dievaluasi dan mungkin diberi penghargaan berdasarkan prestasi mereka pada sasaran. Berikut ini dimensi dalam partisipasi anggaran keterlibatan aparat pemerintah dalam penyusunan anggaran, merevisi anggaran, usulan tentang anggaran, banyaknya input, memandang kontribusi/pendapat dalam penyusunan anggaran. Variabel partisipasi penyusunan anggaran diukur dengan menggunakan skala LIKERT antara 1 sampai dengan 5. Skor terendah (1) dari jawaban responden menunjukkan rendahnya partisipasi penyusunan anggaran dan skor tinggi (5) menunjukkan tingginya partisipasi penyusunan anggaran.

\section{Kinerja Manajerial}

Kinerja manajerial adalah seberapa efektif dan efisien yang dicapai oleh pejabat struktural SKPD, sebagai pengguna anggaran dalam bekerja untuk mencapai tujuan instansi. Variabel kinerja manajerial dalam penelitian ini akan diukur dengan menggunakan instrument yang dilakukan oleh Pramesthiningtyas (2011). Pengukuran ini menggunakan delapan butir pertanyaan yang meliputi perencanaan, investigasi, pengkoordinasian, evaluasi, pengawasan, pengaturan staf, negosiasi dan perwakilan atau representasi. Variabel kinerja manajerial diukur dengan menggunakan skala LIKERT antara 1 sampai dengan 5. Skor terendah (1) dari jawaban responden menunjukkan rendahnya kinerja aparat pemerintah daerah dan skor tinggi (5) menunjukkan tingginya kinerja manajerial.

\section{Motivasi Kerja}

Motivasi merupakan suatu proses yang dimulai dengan kebutuhan fisiologis atau psikologis yang berupa aktivitas perilaku atau mendorong maksud dalam tujuan instansi. Variabel motivasi kerja dalam penelitian ini akan diukur dengan menggunakan instrument yang dikembangkan oleh Maslow dalam Pramesthiningtyas (2011). Setiap responden diminta menjawab enam butir pertanyaan untuk mengukur motivasi dalam bekerja dan pengaruh yang dirasakan serta kontribusi responden dalam proses bekerja. Variabel motivasi kerja diukur dengan menggunakan skala LIKERT antara 1 sampai 
dengan 5. Skor terendah (1) dari jawaban responden menunjukkan rendahnya kinerja aparat pemerintah daerah dan skor tinggi (5) menunjukkan motivasi kerja.

\subsection{Teknik Analisis Data}

\subsubsection{Statistik Deskriptif}

Gambaran umum mengenai responden dijelaskan dengan table distribusi frekuensi yang menunjukan umur, pendidikan responden, lamanya bekerja di perusahaan, dan jumlah jawaban. Sedangkan untuk memberikan deskripsi tentang karakter variabel penelitian mengenai variablevariable penelitian yaitu orientasi professional, dan konflik peran, digunakan tabel distribusi frekuensi yang menunjukkan angka modus, kisaran skor dan standar deviasi. Penggunaan modus ditunjuk untuk mengetahui lebih akurat ukuran terbensi pusat masing-masing data variabel penelitian sehingga dapat diketahu kecenderungan dominasi jawaban responden.

\subsubsection{Pengujian Hipotesis}

Metode statistik yang digunakan untuk menguji hipotesis adalah regresi sederhana dan analisis regresi bertingkat dengan pendekatan uji interaksi Moderating Regresi Aanalysis (MRA). Metode regresi sederhana digunakan untuk melihat hubungan langsung antara partisipasi anggaran dan kinerja manajerial, sedangkan analisis regresi bertingkat dengan pendekatan uji interaksi digunakan untuk melihat pengaruh partisipasi anggaran dan kinerja manajerial dengan motivasi kerja sebagai variabel moderating/interaksi. Model analisis yang digunakan adalah sebagai berikut:

$$
\mathbf{Y}=\mathbf{a}+\boldsymbol{\beta} 1 \mathrm{X} 1+\boldsymbol{\beta} 2[\{\mathrm{X} 1 * \mathrm{X} 2\}]+\mathrm{e}
$$

Dimana :

$$
\begin{array}{ll}
\mathrm{Y} & =\text { Kinerja Manajerial } \\
\mathrm{X}_{1} & =\text { Partisipasi Anggaran } \\
\mathrm{X}_{2} & =\text { Motivasi Kerja } \\
\beta 1 & =\text { Koefisien dari partisipasi anggaran } \\
\beta 2 & =\text { Koefisien dari motivasi kerja } \\
a & =\text { Konstanta } \\
e & =\text { Error }
\end{array}
$$

\section{HASIL PENELITIAN DAN PEMBAHASAN}

\subsection{Gambaran Umum Responden}

Penelitian ini dilakukan pada Organisasi Perangkat Daerah (OPD) Kota Jayapura yang terdiri dari 33 OPD. Adapun waktu penelitian berlangsung dari bulan November 2017 hingga Januari 2018. Dari sebanyak 99 eksemplar kuesioner yang didistribusikan pada Organisasi Perangkat Daerah (OPD) Kota Jayapura ada 70 kuesioner yang dikembalikan dan dapat digunakan sebagai data pengolahan dan yang tidak dikembalikan sebanyak 20 buah kuesioner.

\subsection{Analisis Data}

Statistik deskriptif digunakan untuk memberikan gambaran mengenai variabel-variabel penelitian. Tabel statistik deskriptif menunjukkan angka kisaran teoritis dan sesungguhnya, rata-rata dan standar deviasi. Pengukuran variabel dalam penelitian ini dengan statistik deskriptif sejumlah 70 Responden, di mana variabel tersebut adalah partisipasi anggaran, kinerja manajerial dan motivasi kerja. Hasil statistik deskriptif dapat dilihat pada tabel 1 berikut ini. 
Tabel 1

Hasil Statistik Deskriptif

\begin{tabular}{|l|r|r|r|r|r|r|r|r|}
\hline & \multicolumn{1}{|c|}{$\mathrm{N}$} & \multicolumn{1}{|c|}{ Ranqe } & Minimum & Maximum & \multicolumn{2}{|c|}{ Mean } & $\begin{array}{c}\text { Std. } \\
\text { Deviation }\end{array}$ & Variance \\
\cline { 2 - 9 } & Statistic & Statistic & Statistic & Statistic & Statistic & Std. Error & Statistic & Statistic \\
\hline Partisipasi Anggaran & 70 & 10.00 & 20.00 & 30.00 & 25.0000 & .26297 & 2.20013 & 4.841 \\
Kinerja Manajerial & 70 & 17.00 & 28.00 & 45.00 & 37.8429 & .40882 & 3.42047 & 11.700 \\
Motivasi Kerja & 70 & 8.00 & 22.00 & 30.00 & 25.8571 & .28070 & 2.34852 & 5.516 \\
Valid N (listwise) & 70 & & & & & & & \\
\hline
\end{tabular}

Sumber: data diolah, 2018

Pada tabel di atas, menunjukkan bahwa partisipasi anggaran mempunyai kisaran teoritis antara 20.00 sampai dengan 30.00 dengan nilai rata-rata sebesar 25.0000 dan standar deviasi sebesar 2.20013. Nilai standar deviasi menunjukkan adanya penyimpangan 4.841 dari rata-rata jawaban responden atas faktor-faktor yang mempengaruhi kinerja manajerial yang besarnya 20.00.

Kinerja manajerial mempunyai kisaran teoritis antara 28.00 sampai dengan 45.00 dengan nilai rata-rata sebesar 37.8429 dan standar deviasi sebesar 3.42047. Nilai standar deviasi menunjukkan adanya penyimpangan 11.700 dari rata-rata jawaban responden atas faktor-faktor yang mempengaruhi motivasi kerja yang besarnya 28.00 .

Motivasi kerja mempunyai kisaran teoritis antara 22.00 sampai dengan 30.00 dengan nilai ratarata sebesar 25.8751 dan standar deviasi sebesar 2,34852. Nilai standar deviasi menunjukkan adanya penyimpangan 5.516 dari rata-rata jawaban responden atas faktor-faktor yang dipengaruhi oleh partisipasi anggaran dan kinerja manajerial yang besarnya 22.00.

\subsection{Pengujian Hipotesis}

Penelitian ini menguji hipotesis dengan metode analisis regresi berganda (multiple Regression) dengan bantuan SPSS versi 21.00. uji hipotesis dilakukan dengan dua cara, pertama dengan melakukan uji signifikan parameter individual (uji statistik $\mathrm{t}$ ) dan kedua menggunakan model analisis MRA/moderasi.

\subsubsection{Pengaruh Partisipasi Anggaran Terhadap Kinerja Manajerial Analisis Linear Berganda}

Analisis linier berganda digunakan untuk mengetahui besarnya pengaruh partisipasi anggaran (X) terhadap kinerja manajerial (Y). Sebagai dasar dalam penghitungan ini digunakan model regresi linier berganda yaitu sebagai berikut :

Tabel 2

Ringkasan Hasil Analisis Regresi

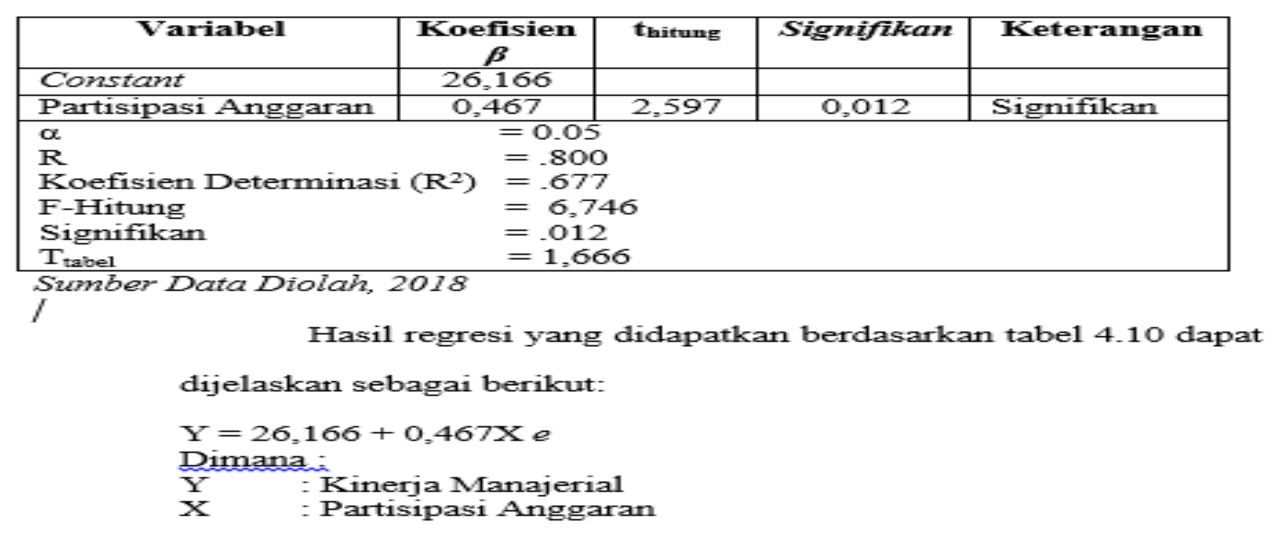


a. 26,166 adalah bilangan konstanta yang berarti apabila variabel bebas yaitu $\mathrm{X}$ sama dengan nol, maka besarnya variabel Y (kinerja manajerial) adalah 26,166. Dengan kata lain jika variabel bebas partisipasi anggaran nilainya dianggap nol berarti kinerja manajerial sebesar 26,166.

b. 0,467 adalah besarnya koefisien regresi variabel bebas $\mathrm{X}$ partisipasi anggaran yang berarti setiap peningkatan (penambahan) variabel $\mathrm{X}$ partisipasi anggaran akan meningkatkan variabel terikat Y (kinerja manajerial) sebesar 0,467. Dengan asumsi variabel bebas lainnya konstan. Jika variabel partisipasi anggaran ada kecenderungan meningkat sebesar 0,467 maka kinerja manajerial akan meningkat sebesar 0,467. Jika variabel partisipasi anggaran ada kecenderungan menurun, maka kinerja manajerial juga akan menurun.

\section{Koefisien Determinasi}

Uji koefisien determinasi digunakan untuk menguji goodnes-fit dan model regresi. Dalam penelitian ini uji koefisien determinan digunakan untuk melihat berapa besar variabel independent mampu menjelaskan variabel dependent. Dengan kata lain koefisien determinan digunakan untuk mengukur kemampuan variabel partisipasi anggaran (X) mempunyai pengaruh terhadap kinerja manajerial (Y1).

Tabel 3

Hasil Uji Koefisien Determinasi

\begin{tabular}{l|c|r|r|r|r|}
\hline & & & & Std. Error of the & Durbin-Watson \\
Model & $\mathrm{R}$ & R Square & Adjusted R Square & $\begin{array}{c}\text { Estimate } \\
\end{array}$ \\
\hline 1 & $.800^{\circ}$ & .690 & .677 & 3.28636 & 1.883 \\
\hline
\end{tabular}
a. Predictors: (Constant), Partisipasi Anggaran
b. Dependent Variable: Kinerja Manajerial
Sumber : data diolah 2018

Berdasarkan tabel 3 dapat diketahui besarnya koefisien korelasi (R) sebesar 0,800 yang berarti bahwa korelasi/hubungan antara variabel partisipasi anggaran sebesar $80 \%$ sedangkan nilai $\mathrm{R}$ square atau nilai koefisien determinasi sebesar 0,690 yang berarti bahwa variabel independent (partisipasi anggaran mampu menjelaskan variabel dependent (kinerja manajerial) sebesar 69\% dan selebihnya sebesar 31\% dapat dijelaskan oleh faktor-faktor lain selain partisipasi anggaran.

\section{Uji T}

Uji signifikan parameter individual (uji statistik t) pada dasarnya menunjukkan seberapa jauh pengaruh satu variabel penjelas atau independen secara individual dalam menerangkan variasi variabel dependen. Pengujian ini bisa dilakukan dengan melihat $p$-value dari masing-masing variabel.

Tabel 4

Hasil Uji Parameter Individual (Uji t)

\begin{tabular}{|c|c|c|c|c|c|c|}
\hline & & \multicolumn{2}{|c|}{$\begin{array}{l}\text { Unstandardized } \\
\text { Coefficients }\end{array}$} & \multirow{2}{*}{$\begin{array}{c}\begin{array}{c}\text { Standardized } \\
\text { Coefficients }\end{array} \\
\text { Beta } \\
\end{array}$} & \multirow[b]{2}{*}{$\mathrm{t}$} & \multirow[b]{2}{*}{ Sig. } \\
\hline \multicolumn{2}{|c|}{ Model } & $B$ & Std. Error & & & \\
\hline \multirow[t]{2}{*}{1} & (Constant) & 26.166 & 4.513 & & 5.798 & .000 \\
\hline & Partisipasi Anggaran & .467 & .180 & .300 & 2.597 & .012 \\
\hline
\end{tabular}

Pengujian model regresi digunakan untuk mengetahui apakah variabel independent pembentuk model regresi memiliki pengaruh yang signifikan terhadap kinerja manajerial atau tidak. Uji ini 
dilakukan untuk menguji apakah variabel partisipasi anggaran (X) atau individu mempunyai pengaruh terhadap kinerja manajerial (Y). untuk menguji hubungan tersebut, digunakan uji t, yakni dengan membandingkan nilai $t_{\text {hitung }}$ dengan $t_{\text {tabel }}$. Variabel independent pembentuk model regresi dikatakan berpengaruh signifikan jika $t_{\text {hitung }}>t_{\text {tabel }}$ atau signifikan $<\alpha=0,05$.

Dengan menggunakan bantuan software SPSS versi 21.00, didapatkan statistik uji t terhadap partisipasi anggaran (X) diperoleh $t_{\text {hitung }}$ sebesar 2,597 dengan signifikan sebesar 0,012. Nilai statistik uji thitung tersebut lebih besar daripada $\mathrm{t}_{\text {tabel }}(2,597>1,666)$ dan juga signifikan lebih kecil daripada $\alpha$ $=0,05$. Pengujian ini menunjukkan bahwa $\mathrm{H}_{\mathrm{a}}$ diterima sehingga dapat disimpulkan bahwa partisipasi anggaran berpengaruh positif terhadap kinerja manajerial.

\subsubsection{Pengaruh Partisipasi Anggaran Terhadap Kinerja Manajerial Dengan Motivasi Kerja Sebagai Variabel Moderasi}

Untuk mengetahui adanya pengaruh antara variabel partisipasi anggaran terhadap kinerja manajerial dengan motivasi kerja sebagai variabel moderasi, digunakan uji interaksi atau disebut moderated regretion analysis. Berdasarkan hasil pengujian yang dilakukan diperoleh nilai-nilai yang tercantum dalam tabel 5.

\section{Tabel 5}

Hasil Regresi Berganda Motivasi Kerja dalam Memoderasi Partisipasi Anggaran Terhadap Kinerja Manajerial

\begin{tabular}{|c|c|c|c|c|c|}
\hline \multirow[b]{2}{*}{ Model } & \multicolumn{2}{|c|}{$\begin{array}{l}\text { Unstandardized } \\
\text { Coefficients }\end{array}$} & \multirow{2}{*}{$\begin{array}{c}\begin{array}{c}\text { Standardized } \\
\text { Coefficients }\end{array} \\
\text { Beta } \\
\end{array}$} & \multirow[b]{2}{*}{$\mathrm{t}$} & \multirow[b]{2}{*}{ Sig. } \\
\hline & B & Std. Error & & & \\
\hline 1 (Constant) & 6.727 & 23.060 & & .292 & .771 \\
\hline Partisipasi Anggaran & -151 & .927 & .141 & .163 & .871 \\
\hline Kinerja Manajerial & .388 & .584 & .565 & .665 & .509 \\
\hline MODERAT & .001 & .023 & .042 & .030 & .976 \\
\hline
\end{tabular}

Sumber: data diolah 2018

Berdasarkan tabel 5 dapat diketahui bahwa ternyata tidak terdapat pengaruh antara variabel motivasi kerja dalam memoderasi partisipasi anggaran dengan kinerja manajerial yang ditunjukkan dengan nilai t hitung sebesar 0,030 dengan signifikasi sebesar 0,976 yang lebih besar dari $\alpha=0,05$.

\subsection{Pembahasan}

\subsubsection{Pengaruh Partisipasi Anggaran Terhadap Kinerja Manajerial}

Dari hasil analisis diperoleh nilai thitung untuk variable partisipasi anggaran sebesar 2,597 dengan tingkat signifikansinya sebesar 0,012. Dengan tingkat signifikansi yang lebih kecil dari $0,05 \mathrm{maka}_{1}$ dapat terdukung atau dengan kata lain partisipasi anggaran berpengaruh terhadap kinerja manajerial. Hal ini membuktikan bahwa partisipasi anggaran memiliki pengaruh positif terhadap kinerja manajerial. Hasil penelitian ini mendukung teori agensi bahwa sebagai agen yang melaksanakan tugas- tugas dari masyarakat, pihak yang terlibat dalam perencanan dan pelaksanaan anggaran mempunyai tanggung jawab untuk melaksanakan amanat dari masyarakat. Hasil yang sama juga diperoleh Fahmi dan Bastian (2001) Menunujukkan bahwa hubungan positif antara partpatisipasi penyusunan anggaran terhadap kinerja manajerial pada tingkat signifikan 5\%.

Dari hasil pengujian hipotesis pertama menyatakan bahwa partisipasi anggaran berpengaruh positif dan signifikan terhadap kinerja manajerial. Para manajer menengah dan bawah (pengguna dan kuasa pengguna anggaran/ barang) pada pemerintah Kota Jayapura terlibat atau ikut serta dalam anggaran, karena dengan adanya partisipasi dalam anggaran, mereka diberi kesempatan untuk berperan dalam memberikan masukan- masukan dan ide- ide mereka yang dituangkan dalam bentuk 
anggaran yang nantinya akan mereka laksanakan. Para pengguna dan kuasa pengguna anggaran/ barang pada Pemerintah Kota Jayapura merasa lebih senang bekerja atas dasar anggaran yang disusunnya sendiri dibandingkan dengan anggaran yang telah ditetapkan oleh atasan mereka dan mereka merasa bertanggung jawab terhadap apa yang telah ditetapkan dalam anggarannya. Selain itu penerapan partisipasi anggaran juga memungkinkan para pengguna dan kuasa pengguna anggaran/ barang pada Pemerintah Kota Jayapura terdorong untuk membantu atasan dengan memberikan informasi yang dimilikinya sehingga anggaran yang disusun lebih akurat karena para bawahan memiliki informasi khusus tentang kondisi lokal dan akan melaporkan kondisi tersebut ke atasan.

\subsubsection{Pengaruh Partisipasi Anggaran Terhadap Kinerja Manajerial Dengan Motivasi Kerja Sebagai Variabel Moderasi}

Dari hasil analisis diperoleh tidak terdapat pengaruh antara variabel motivasi kerja dalam memoderasi partisipasi anggaran dengan kinerja manajerial yang ditunjukkan dengan nilai t hitung sebesar 0,030 dengan signifikasi sebesar 0,976 yang lebih besar dari $\alpha=0,05$. Dengan demikian, hasil penelitian ini menyatakan bahwa peningkatan motivasi kerja tidak menyebabkan peningkatan terhadap kinerja manajerial yang berpatisipasi dalam anggaran. Sebaliknya penurunan motivasi kerja tidak berakibat pada terjadinya kecenderungan untuk menurunnya kinerja manajerial dalam berpartisipasi menyusun anggaran. Motivasi kerja yang dilakukan oleh aparat pemerintah dalam hal ini OPD dalam meningkatkan kinerja tidak menjadi masalah yang mendukung adanya penurunan kinerja. Adanya motivasi kerja yang tinggi dari aparatur tidak selamanya dapat memberikan hasil yang baik bagi kinerja aparat pemerintah pada suatu daerah atau pemerintahan.

Hasil penelitian ini menolak penelitian yang dilakukan oleh Nanik Ermawati (2017) yang menyatakan motivasi mampu memoderasi partisipasi anggaran terhadap kinerja manajerial dan mendukung penelitian yang dilakukan oleh (Randall ,1990) dalam Nouri dan Parker (1998). Peningkatan partisipasi anggaran tidak meningkatkan kinerja aparat pemerintah dengan adanya kepedulian dan perhatian terhadap motivasi kerja para bawahan dalam berpartisipasi untuk menyusun anggaran. Motivasi kerja yang tinggi tidak meningkatkan kinerja yang tinggi pula motivasi kerja yang rendah dari aparat pemerintah daerah tidak berimplikasi pada rendahnya kinerja manajerial untuk bertanggung-jawab terhadap tujuan sasaran anggaran yang hendak dicapai.

\section{PENUTUP}

\subsection{Kesimpulan}

Berdasarkan hasil pembahasan, maka dapat ditarik beberapa kesimpulan sebagai berikut :

Partisipasi anggaran berpengaruh signifikan terhadap kinerja manajerial. Ini berarti bahwa partisipasi anggaran memiliki pengaruh yang positif terhadap kinerja manajerial, dengan kata lain semakin baik partisipasi anggaran maka kinerja manajerial yang ada pun akan semakin meningkat.

Tidak terdapat pengaruh signifikan antara variabel motivasi kerja dalam memoderasi partisipasi anggaran dengan kinerja manajerial, yang ditunjukkan dengan nilai thitung sebesar 0,030 dengan signifikasi sebesar 0,976 yang lebih besar dari $\alpha=0,05$. hasil ini menunjukkan semakin tinggi motivasi kerja yang dimiliki tidak menyebabkan peningkatan kinerja manajerial untuk berpatisipasi dalam penyusunan anggaran. 


\subsection{Saran}

Dari kesimpulan diatas, maka saran kepada penelitian selanjutnya antara lain :

1. Para pejabat kepala dinas pemerintah Kota Jayapura hendaknya melibatkan seluruh Kabag/kasubag dari setiap OPD untuk berpartisipasi dalam penyusunan anggaran.

2. Terkait motivasi kerja di lingkungan pemerintah Kota Jayapura perlu memberikan motivasi bagi para kabag/kasubag untuk berpartipsi dalam penyusuna anggaran demi tercapainya tujuan sasaran anggaran.

3. Penelitian ini diharapkan dapat dijadikan sebagai sumber referensi bagi penelitian selanjutnya, terutama mengenai partisipasi anggaran terhadap kinerja manajerial dengan motivasi kerja sebagai variabel moderating. 


\section{DAFTAR PUSTAKA}

Abdullah, M dan Laksmana, A, 2012. Pengaruh persepsi ketidakpastian lingkungan terhadap orientasi efisiensi, pendelegasian wewenang, pengendalian akuntansi dan kinerja manajer. Ekuitas: Jurnal Ekonomi dan keuangan. Vol. 16 No.3. STIESIA. Surabaya. Diakses pada tanggal 25 Desember 2017 https://ejournal.stiesia.ac.id/ekuitas/article/view/2328.

Allen J, Natalie \& Meyer, John P. 1990. The Measurement and Antecedents of Affective, Continuance and Normative Commitment to The Organization. Journal of Occupational Psychology. Vol 63.

Abdullah, Syukriy dan Abdul halim. 2004. Perilaku Oportunistik Legislatif Dalam Penganggaran Daerah: Pendekatan Principal-agent Theory. Makalah Seminar Antarbangsa di Universitas Bengkulu, Bengkulu, 4-5 Oktober 2004. Diakses pada tanggal 27 Desember 2017 scholar.google.co.id/citations?user=1Q1I5-gAAAAJ\&hl=en.

Bastian, Indra. 2006. Akuntansi Sektor Publik. Suatu pengantar. Yogyakarta : Erlangga.

Badjuri, Achmad. 2009. Pengaruh Komitmen Organisasional dan Professional terhadap Kepuasan Kerja Auditor dengan Motivasi sebagai Variabel Intervening (Studi pada KAP di Jawa Tengah dan DIY). Jurnal Kajian Akuntansi. Vol. 1 No. 2. Universitas Stikubank. Semarang.

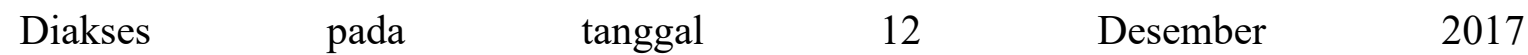
https://www.unisbank.ac.id/ojs/index.php/fe4/article/view/2065.

Brownell. P. and McInnes, M. 1986. "Budgetary Participation, Motivation, and Manajerial Performance". The Accounting Review, Vol. 61, No. 4.

Brownell. P. 1981. Participation in Budgeting Locus of Control and Organizational Effectiveness. The Accounting Review 57, PP. 766-777.

Cherrington, D. J. / Cherrington, J. O. 1973. "Appropriate Reinforcement Contingencies in the Budgeting Process". Journal of Accounting Research Supplement. 11: 225-253.

Chong, V.K. and Chong K. M, 2002. Budget Goal Commitment andInformational Effects of Budget Participation on Performance: A Structural Equation Modeling Approach. Bahavioral Research In Accounting. Volume 14, 2002.

Dharma, Emile Setia, 2004. Pengaruh Kejelasan Sasaran Anggaran dan Sistem Pengendalian Akuntansi Terhadap Kinerja Manajerial dengan Komitmen Organisasi sebagai Variabel Pemoderasi Pada Pemerintah Daerah. SNA VII. Denpasar. Diakses pada tanggal 12 Desember 2017 https://online-journal.unja.ac.id/index.php/JES/article/view/3501.

Eker, Melek. 2007. "The Impact Of Budget Participation On Managerial Performance Via Organizational Commitment : A Study On The Top 500 Firms In Turkey”. Jurnal tidak $\begin{array}{lllll}\text { dipublikasikan. Diakses pada tanggal } 27 & \text { Desember } 2017\end{array}$ ojs.unmas.ac.id/index.php/JUARA/article/view/865.

Faculty of Economy, Ankara University Turkey. Fisher, Joseph G, 1998. Contingency Theory, Management Control System and Firm Outcome: Past Results and Future Directions. Behavioral Research in Accounting, 1998 Supplement. Vol. 10, pp 47. 
Frucot, V and Shearon, W.T. 1991. Budgetary Participation, Locus of Control, and Mexican Managerial Performance and Job Satisfaction. The Accounting Review. Pp. 88-99.

Ghozali, Imam. 2006. Aplikasi Analisis Multivariate dengan Program SPSS. Badan Penerbit-UNDIP. Semarang.

Gugus Irianto dan Nurkholis. 2006. Pengaruh Karakteristik Tujuan Anggaran Terhadap Perilaku, Sikap, Dan Kinerja Aparat Pemerintah Daerah Di Kabupaten Kupang. SNA 9. Padang.

Govindarajan, Vijay. 1986. Impact of Participation in The Budgetary Procces on Manajerial Attitudess and Performance: Universallistic and Contigency Perspectives. Decision Sciences 17. Pp 496-516.

Ghozali dan Yusfaningrum. 2006. Pengaruh Partisipasi Anggaran Terhadap Kinerja Manajerial Melalui Komitmen Tujuan Anggaran dan Job Relevant Information Sebagai variabel Intervening. Usahawan No 07 TH XXXV Juli, Hal. 7-13.

Hafiz, Frisilia Wihasfina. 2007. Pengaruh Partisipasi Anggaran Terhadap Kinerja Manajerial Pada PT Cakra Compact Aluminium Industries. Fakultas Ekonomi Universitas Sumatra Utara. $\begin{array}{lllll}\text { Medan. Diakses } & \text { pada tanggal } & 10 & \text { Desember }\end{array}$ repository.usu.ac.id/bitstream/handle/123456789/9559/08E01515.pdf? sequence=1.

Hariyono, Anwar. 2010. Partisipasi Penyusunan Anggaran dan Kejelasan Sasaran Anggaran Terhadap Kinerja Manajerial Dengan Komitmen Organisasi Sebagai Pemoderasi dan Job Relevant Information Sebagai Intervening. Jurnal Ekonomi. Volume 1 Nomer 1. Universitas Muhamadiyah Gresik.

Hasibuan. 2009. Manajemen Sumber Daya Manusia. Edisi Revisi Cetakan ke 13. PT Bumi Aksara. Jakarta.

Hansen dan Mowen (Terjemahan). 2004. Akuntansi Manajemen. Edisi Ketujuh. Salemba Empat. Jakarta.

Hoque, Zahirul dan Peter Brosnan. 2007. Alligning Industrial Relatoins Risk, Budgetary Partcipation, and Budgating Measures of Performance: Impact on Managerial Performance. SSRN. 2007.

Hariyanti dan Nasir. 2002. Pengaruh Penyusunan Anggaran terhadap Kinerja Manajerial: Peran Kecukupan Anggaran dan Komitmen Organisasi sebagai Variable Intervening. Simposium Nasional Akuntansi V. Semarang.

Indriantoro, N. 1993. The Effect of Participative Budgeting on Job Performance and Job Satisfaction withLocus of Control and Cultural Dimensions as Moderating Variabels. Makalah Stadium Generale di STIE Widya Wiwaha, Yogyakarta. Diakses pada tanggal 17 Desember 2017 sitedi.uho.ac.id/uploads_sitedi/G2E114036_sitedi_JURNAL.pdf.

Kurniawan, Shodiq. 2012. Pengaruh Partisipasi Penyusunan Anggaran Terhadap Kinerja Manajerial melalui Kepuasan Kerja, Motivasi Kerja dan Job Relevant Information Sebagai Variabel Moderating dan Komitmen Organisasi sebagai variabel intervening, E-Jurnal. 
Universitas Islam Indonesia. Yogyakarta. Diakses pada tanggal 20 Desember 2017 https://jom.unri.ac.id/index.php/JOMFEKON/article/viewFile/8124/7796.

Kenis, Izzettin. 1979. Effect of Budgetary Goal Characteristic on Managerial Attitudes and Performance. The Accounting Review. Vol. LIV, No. 4. October: pp. 707- 721.

Kren, Leslie. 1992. Budgetary Participation and Managerial Performance: The Impact of Information and Environment Volatility. The Eccounting Review, July: pp. 511-526.

Kusuma, Octa Gandi. 2013. Analisis Pengaruh Partisipasi Penyusunan Anggaran Terhadap Kinerja Manajerial Dengan Kepuasan Kerja, Informasi Kerja Yang Relevan, Serta Motivasi Kerja Sebagai Variabel Moderating Pada Rumah Sakit Angkatan Laut dan Rumah Sakit Umum Daerah Provinsi Di Provinsi Kepulauan Riau. Jurnal Tesis. Universitas Maritim Raja Ali Haji Tanjung pinang. Diakses pada tanggal 20 Desember 2017 stialanbandung.ac.id/ojs/index.php/jia/article/download/73/pdf.

Luthans, Fred. 1992. Organization Behavior. Sixth Edition. Singapore : MC Graw Hill Book Co.

Locke, E., Latham (1984). Goal Setting. A Motivational Technique That Works. Prentice Hall. Inc Englewood, New Jersey.

Mulyadi. 2001. Akuntansi Manajemen. Cetakan Pertama. Salemba Empat. Jakarta.

Narmodo, H. dan Wajdi, M. Farid. 2007. "Pengaruh Motivasi dan Disiplin Terhadap Kinerja Pegawai Badan Kepegawaian Daerah Kabupaten Wonogiri”. Jurnal Tidak Dipublikasikan. Diakses pada tanggal 25 Desember 2017 https://www.google.co.id/search?dcr=0\&ei=arpn.

Nurcahyani, kunwaviyah. 2010. Pengaruh Partisipasi Anggaran Terhadap Kinerja Manajerial Melalui Komitmen Organisasi Dan Persepsi Inovasi Sebagai Variabel Intervening. Universitas Diponegoro. Semarang. Diakses pada tanggal 25 Desember 2017 https://core.ac.uk/download/pdf/11722146.pdf.

Nurul,K dan Prasetyono. 2007. Analisis Kinerja Rumah Sakit Daerah Dengan Pendekatan Balanced Scorecard Berdasarkan Komitmen Organisasi, Pengendalian Intern Dan Penerapan Prinsip-Prinsip Good Corporate Governance (Gcg) (Survei Pada Rumah Sakit Daerah Di Jawa Timur). Diakses pada tanggal 25 Desember 2017 https://smartaccounting.files.wordpress.com/2011/03/aspp12.pdf.

Putti, Joseph, Harold Koontz, Heinz Weihrich, 1998. Essentials of Management (An Asian Perspective), McGraw-Hill Book Company, Singapore

Pranesti, Gregoria dan Roekhudin. 2001. Analisis Korelasi antara Gaya Kepemimpinan dengan Penerapan Penganggaran Partisipasi,http://www.fe.unibraw.ac.id/tema/Vol-II-1.

Pramesthiningtyas, Arisha Hayu, 2011. Pengaruh Partisipasi Anggaran Terhadap Kinerja Manajerial, Melalui Komitmen Organisasi Dan Motivasi Sebagai Variabel Intervening (Studi Kasus Pada 15 Perusahaan Di Kota Semarang). Diakses pada tanggal 25 Desember 2017 eprints.undip.ac.id/27646/. 
Ridzal, Nining Asniar. 2016. Pengaruh Partisipasi Penyusunan Anggaran, Kejelasan Sasaran Anggaran Dan Komitmen Aparatur Terhadap Kinerja Manajerial Dengan Job Relevant Information Sebagai Variabel Intervening (Studi Pada Pemerintah Kota Baubau). Tesis. Universitas Haluoleo. Kendari (Tidak Dipublikasikan). Diakses pada tanggal 25 Desember 2017 sitedi.uho.ac.id/uploads_sitedi/G2E114030_sitedi_Thesis\%20Nur\%20Laila.pdf.

Slamet, Riyadi. 2000. Motivasi dan Pelimpahan Wewenang sebagai variabel Moderating dalam Hubungan Antara Partisipasi Anggaran dan Kinerja Manajerial. Jurnal Riset Akuntansi Indonesia, Vol. 2, No. 2, Juli 2000. Diakses pada tanggal 20 Desember 2017 jurnal.unissula.ac.id/index.php/jai/article/download/846/685.

Sardjito, Bambang dan Osmad Muthaher, 2007. Pengaruh Partisipasi Penyusunan Anggaran Terhadap Kinerja Aparat Pemerintah Daerah : Budaya Organisasi dan Komitmen Organisasi sebagai Variabel Moderating. Symposium Nasional Akuntansi X. Diakses $\begin{array}{llll}\text { pada } & \text { tanggal } & 20 & \text { Desember }\end{array}$ https://smartaccounting.files.wordpress.com/2011/03/aspp07.pdf.

Sinuraya, Candra, 2009. Pengaruh Partisipasi Penyusunan Anggaran dan Komitmen Organisasi terhadap Kepuasan Kerja dan Kinerja Karyawan. JurnalAkuntansi. Universitas Kristen Maranatha. Vo. 1 No. 1 Mei 2009. Bandung. Diakses pada tanggal 22 Desember 2017 https://ojs.unud.ac.id/index.php/Akuntansi/article/view/9983/8133.

Samuel, Abel Tanta S, 2008. Pengaruh Partisipasi Anggaran dan Kejelasan Sasaran Anggaran Terhadap Kinerja Manajerial dengan Motivasi sebagai Variabel Intervening. Universitas Sumatera Utara: Medan. Diakses pada tanggal 20 Desember 2017 repository.usu.ac.id/bitstream/handle/123456789/4028/047017031.pdf?sequence=1.

Supriyono, 1999. Akuntansi Manajemen I: Konsep Dasar Akuntansi Manajemen Dan Proses Perencanaan. Cetakan Kelima, BPFE-Yogyakarta.Yogyakarta.

Siagian, Sondang P. 2003. Manajemen Sumber Daya Manusia. Jakarta: Bumi Aksara.

Siegel, G dan H.R. Marconi. 1989. Behevioral Accounting. South-Westren Publishing, Co: Cincinati, $O H$. http://www.getcited.org/pub/102642746.

Sukmantari dan Wirasedana, 2015. Pengaruh Partisipasi Penganggaran dan Komitmen Organisasi pada Kinerja Manajerial dengan Kepuasan Kerja sebagai Variabel Intervening. E-Jurnal Akuntansi. Universitas Udayana. Bali. Diakses pada tanggal 20 Desember 2017 https://ojs.unud.ac.id/index.php/Akuntansi/article/view/9983.

Supriyono, R.A, 2004. Pengaruh Variabel Intervening Kecukupan Anggaran dan Komitmen Organisasi terhadap Hubungan Antara Partisipasi Anggaran dan Kinerja Manajerial di Indonesia. Jurnal Ekonomi dan Bisnis, Vol.19, No.3. diakses pada tanggal 25 Desember 2017 https://journal.ugm.ac.id/jieb/article/view/6602.

Suryanawa, Kadek, 2008. Pengaruh partisipasi penyusunan anggaran terhadap kinerja manajerial dengan komitmen organisasi sebagai variabel moderasi pada SKPD Dinas Kabupaten Bandung. Fakultas Ekonomi Universitas. Sumarno, 2005. Pengaruh Komitmen Organisasi dan Gaya Kepemimpinan Terhadap Hubungan Antara Partisipasi Anggaran dan Kinerja 
$\begin{array}{llllllll}\text { Manajerial, } & \text { SNA VII. Solo. Diakses pada tanggal } 20 & \text { Desember } & 2017\end{array}$ https://ojs.unud.ac.id/index.php/jiab/article/download/2629/1843.

Sugiyono. 2008. Metode Penelitian Pendidikan (Pendekatan Kuantitatif, Kualitatif, Dan R\&D). Bandung: Alpabeta.

Silalahi, Ulber. 2012. Metode Penelitian Sosial. Bandung. PT Refika Aditama

T.Hani Handoko, 1996. Manajemen. BPFE : Yogyakarta.

Winener, Y, 1982. Commitment in Organization: A Normative View, Academy of Management Review 7, pp. 418-428.

Yuleova, Dodi. 2013. Pengaruh Komitmen Organisasi dan Komunikasi Terhadap Kinerja Pegawai Dengan Kepuasan Kerja Sebagai Variable Intervening Pada BPBD Propinsi Sumatera Barat. Artikel. Universitas Bung Hatta. Diakses pada tanggal 15 Desember 2017 ejurnal.bunghatta.ac.id/index.php?journal=JPSC2\&page=article\&op.

Yunita. 2008. Pengaruh Partisipasi Penyusunan Anggaran terhadap Kinerja Manajerial: Komitmen Organisasi dan Kecukupan Anggaran sebagai Variable Kontinjen (Studi Kasus Pada Universitass Dian Nuswantoro Semarang). http://eprints.undip.ac.id/8121/1/Yunita.pdf.

2012. Panduan penyusunan tesis dan disertasi. UJM Pascasarjana. Universitas Haluoleo. $\begin{array}{lllll}\text { Kendari. Diakses pada tanggal } 22 & \text { Desember } & 2017\end{array}$ https://luk.staff.ugm.ac.id/riset/panduan/pasca/Tesis2011.pdf. 